\title{
A MULTIDIMENSIONAL TAXONOMY OF DEVELOPMENTAL STATES
}

\author{
Sergio Tezanos ${ }^{\mathrm{a}}$ and Fernando de la Cruz ${ }^{\mathrm{b}}$ \\ Date received: June 6, 2019. Date accepted: November 16, 2019. \\ http://doi.org/10.22201/iiec.20078951e.2020.201.69436
}

\begin{abstract}
This paper proposes a new approach to the classification of Developmental States (DS) based on their public efforts to foster human development. We conceptualize DS within a multidimensional framework that includes three main dimensions (economic, social and democratic), and run a hierarchical cluster analysis for 112 countries in order to build a multidimensional taxonomy of Ds. We propose a countryclassification and characterize three country-groups with different developmental public efforts: $i$ ) the human development States; ii) the unbalanced developmental States and iii) the non-developmental States. Our multidimensional taxonomy offers a more complex understanding of the variety of public efforts devoted to promote human development, thus overcoming the restricted-economical-conception of DS, which is mainly focused to the East Asian region.
\end{abstract}

Key Words: developmental states; multidimensional taxonomy; social equality and democratic participation; welfare states; economic growth.

\section{UNA TAXONOMÍA MULTIDIMENSIONAL DE ESTADOS DESARROLLISTAS}

Resumen. Este trabajo propone un nuevo marco para clasificar a los Estados Desarrollistas (ED) basado en sus esfuerzos para mejorar el desarrollo humano. Se conceptualiza a los ED en un marco multidimensional con tres dimensiones principales (económica, social y democrática) y se realizó un análisis de clúster jerárquico para 112 economías con el fin de construir dicha taxonomía. Se propone una clasificación por país y se clasifican tres grupos en función de sus esfuerzos desarrollistas: i) los Estados de desarrollo humano; ii) los Estados desarrollistas desbalanceados y iii) los Estados nodesarrollistas. La taxonomía multidimensional ofrece un entendimiento más complejo de la variedad de esfuerzos públicos para promover el desarrollo humano, superando así la concepción -económica - restringida de los ED prevaleciente en la región del Este Asiático.

Palabras clave: Estados de desarrollo humano; taxonomía multidimensional; igualdad social y participación democrática; Estados de bienestar social; crecimiento económico.

Clasificación JEL: F43; I31; I38; O15; R13.

${ }^{a}$ Universidad de Cantabria (Uc), Spain; ${ }^{\mathrm{b}}$ Fundación Internacional y para Iberoamérica de Administración y Políticas Públicas, Spain. Email addresses: sergio.tezanos@unican.es and fernando.delacruz@fiiapp.es, respectively. 


\section{INTRODUCTION}

The concept of Developmental States (Ds) gained notoriety during the 1980s and 1990s as a successful explanation for the "East Asian economic miracle". It was argued that the region's rapid economic growth and the modernization of its productive structures were the result of a series of successful industrial policies focused on boosting exports, technology and innovation, paired with fiscal and financial incentives to enhance economic productivity and competitiveness (Johnson, 1982; Amsden, 1989; Wade, 1990).

Drawing on this literature, some authors have recently revisited the DS concept in order to explain the recent socio-economical successes of some emerging economies. In this context, some authors identify the presence of emerging Ds in some developing countries (Malik, 2013), but also in developed countries such as the United States (Block, 2008).

Moreover, one feature stands out among its antecedents: the inclusion of new dimensions of development beyond the traditional economic approach, thus evolving from an economic unidimensional concept to a multidimensional one. This new approach includes both a social dimension (Kwon, 2005 and 2009, Sandbrook et al., 2007; Evans and Heller, 2013) and a democratic dimension (Robinson and White, 1998; Edigheji, 2010). Hence, some authors currently talk about "human development States" as an ideal category of this new multidimensional conception where Ds are defined, beyond income growth, by their ability to expand human opportunities and capacities (Evans and Heller, 2013; Malik, 2013; De la Cruz, 2017; Hsu, 2018; Nem Singh and Ovadia, 2018).

Inevitably, this new multidimensional conception of the Ds challenges the traditional dichotomy of either being a Ds or not, and thus opens the door for exploring the different typologies of Ds derived from a multidimensional conception. This is the main objective of this paper, which offers an international and multidimensional taxonomy of DS in order to evaluate public efforts to promote human development around the world.

To that end this paper is structured into five sections, including this introduction: firstly, we review the theoretical evolution from an unidimensional to a multidimensional conception of DS. Secondly, we describe the methodology used to build an international taxonomy of Ds by means of a hierarchical cluster analysis. Then we explain the main results of the classification. Finally, we draw the main conclusions and explore the implications of using a multidimensional taxonomy of DS. 


\section{CONCEPTUALIZATION OF DEVELOPMENTAL STATES: FROM UNIDIMENSIONALITY TO MULTIDIMENSIONALITY}

Traditionally, Ds has been conceptualized as States that experience rapid economic growth (in terms of income per capita) and productive structure modernization. This economical conception of Ds has endured over two centuries, from the seminal contributions of Hamilton and List, to the most recent studies on the East Asian economic miracle (Amsden, 1989; Wade, 1990; Woo-Cumings, 1999). ${ }^{1}$ In part, this economical conception of DS was associated with the hegemony of the economic theory on the conceptualization of "development", simplifying the concept mainly to "income growth" (Evans and Heller, 2013).

However, in the second half of the $20^{\text {th }}$ century, with the emergence of the multidisciplinary field of "development studies", several researchers questioned the economical conception of DS and stressed the need for wider analytical approaches (Seers, 1969; Streeten, 1984; Sen, 1999). This long road was initiated through the "basic needs approach" and it gained maturity and integrity with the "human development approach". Human development is understood as a process of expansion of the freedoms acquired through an interaction between individual capacities and the opportunities provided by the environment, or, in Amartya Sen's terms:

The expansion of freedom is viewed in this approach both as the primary end and as the principal means of development. Development consists of the removal of various types of unfreedoms that leave people with little choice and little opportunity of exercising their reasoned agency. The removal of substantial unfreedoms, it is argued here, is constitutive of development (Sen, 1999, Preface XII).

Following Sen's definition, we can derive that the focus on the expansion of freedom implies two break ups from the traditional economic conceptualization of development:

Firstly, the human development approach understands income increases as a "means" to the expansion of human freedoms, not as an "end" itself. As a result, income growth becomes one of the possible drivers of development, but it is not the only one; many others exist, such as educational and health improvements (social capital) and democratic participation (political capital),

\footnotetext{
For an extensive review of the literature on Ds see Routley (2012) and De la Cruz (2014).
} 
for instance. From this perspective, development has a broader nature and determining factors, transitioning from a process of economic capital accumulation to a process of human capital accumulation and redistribution. As a result, new dimensions emerged to explain different paths to increasing individual freedoms, thus transitioning from unidimensionality to multidimensionality in the conception of the development process. ${ }^{2}$

Secondly, and as a result of the previous argument, the human development approach questioned the traditional wisdom on the relation between the different channels (dimensions) that lead to development. Traditionally, the economic thought understood these relationships as a trade-off (accumulation $v$ s. redistribution) or merely as independent variables (accumulation and political regime), but did not consider positive feedbacks between them. However, several recent empirical studies have tested these relationships, demonstrating that, at least, the trade-off is not the only possible direction, and that in many cases positive loops can take place ("multiplier effect"), thus opening the door to multidimensional-reinforced -instead of substitutiveapproaches in the pursuit of human development. ${ }^{3}$

Finally, should be mentioned that the proposals on the multidimensionality of development are not limited to the human development approach. Notable progress has been made from other areas, such as gender approaches (Boserup, 2007) and environmental approaches to sustainable development (Redclift and Springett, 2015). These approaches have extended the multidimensional concept of development, integrating new and complementary dimensions into the general framework of the expansion of freedoms and capabilities.

Among others, the sustainable development approach -intimately linked to the challenges facing the Planet- has gained notoriety. As it affects economic, political, social and cultural dynamics, sustainable development must be tackled from a transversal perspective. Accordingly, some approaches to the developmental State have been developed from this environmental

For an extensive discussion on the scope and multidimensionality of human development see, among many others, Nussbaum (2001) and Alkire (2002).

3 See, among others, Ostry and Berg (2011) and Berg et al. (2012) on the positive relationship between social equality and economic growth in the long run; Besley and Kudamatsu (2006 and 2007), McGuire (2010) and Gerring et al. (2012) on the positive relationship between democracy and human development; Ostry et al. (2014) on the positive effect of social redistribution on economic development; Hanushek and Woessmann (2008 and 2012) on the positive effect of cognitive development spending on economic growth; and Ranis et al. (2000 and 2006) on the positive effect of human development on economic growth. There is still no clear evidence of the direction of the relationship between democracy and economic growth (Barro, 1996; Doucouliagos and Ulubaşoğlu, 2008). 
perspective (and are connected, in a broader sense, with the globally widespread proposals of Green New Deals, i.e. the structural transformation of the economy from an environmentaly sustainabile perspective) (Wong, 2012; Swilling et al., 2016).

In this sense, and from a conceptual perspective, we draw on the concept of human development proposed by Sabina Alkire, that incorporates in its definition the sustainable development approach as follows:

Human development aims to expand people's freedoms -the worthwhile capabilities people value- and to empower people to engage actively in development processes, on a shared planet. And it seeks to do so in ways that appropriately advance equity, efficiency, sustainability and other key principles (Alkire, 2010, p. 24).

Therefore, the human development approach has redefined the conception of development, offering a broader understanding that highlights the importance and complexity of multidimensionality. Consequently, the framework linked to the conceptualization of the Ds has also shifted towards a new multidimensional conception of DS, in line with the human development approach (Leftwich, 1995; Robinson and White, 1998; Kwon, 2005 and 2009; Sandbrook et al., 2007; Evans, 2008; Edigheji, 2010; Hayashi, 2010; Malik, 2013; Evans and Heller, 2013).

The concept of "multidimensional Ds" implies a broader approximation to State interventions in order to achieve human development. Although the economic dimension remains central, new dimensions have been added for State interventions to foster human capacities and opportunities. In particular, there is a wide consensus on the need to include two new dimensions: social equality and democratic participation (Routley, 2012). These two dimensions entail both new public structures (such as the institutions typical of welfare State) and new relationships between public institutions, the civil society and the private sector (Hsu, 2018). Moreover, new instruments and incentives are also considered in these two dimensions in order to provide social redistribution and democratic participation (Evans and Heller, 2013). ${ }^{4}$

The economic dimension of this new conception of multidimensional DS remains similar to the traditional economical conception of DS. However, as

4 Initially the environmental sustainability dimension was also considered. However, due to methodological reasons, mainly linked to the lack of homogeneous and reliable data at the international level, it was ruled out. For a further explanation on this issue, see De la Cruz (2017). 
some authors have pointed out, bilateral (Shadlen, 2005) and global (Wade, 2003) trade agreements, as well as global trade networks (Yeung, 2014), have placed important limitations on the industrial policies of Ds, particularly on their respective incentives on taxation, trade and finance. Some authors argue that the economic dimension has been progressively restricted to research, innovation and education linked to industrial policies (Mazzucato, 2013), while maintaining traditional institutional quality and performance (Evans, 1995).

In relation to the social dimension, public structures are any type of structure that form the welfare State (i.e. all public social policies that have a direct impact on improving the skills and opportunities of citizens).

Within this framework, the relationships between civil society agents and the welfare state bureaucracy are particularly relevant, as well as the public instruments and incentives directed towards the efficient provision of social services (Sandbrook et al., 2007; Malik, 2013).

Finally, the democratic dimension involves all public structures linked to the provision of political rights, expression and participation, which thus allow for the expansion of freedoms associated with these rights. This approach breaks away from the traditional conception of semi-authoritarian DS, focusing instead on transparency, accountability, participatory policies and political rights (Evans and Heller, 2013).

\section{METHODOLOGY: A CLUSTER ANALYSIS OF MULTIDIMENSIONAL DEVELOPMENTAL STATES}

Traditionally, the study of Ds has been focused on countries with accelerated levels of economic growth, in line with the unidimensional concept of economic development. Methodologically, these analyses consisted of case (country) studies and comparative (regional) studies, mainly focused on the East Asian region. As a result, they offered deep explanations of the functioning patterns of public structures and their link to economic development.

However, methodological limitations arise when using a multidimensional concept of Ds. Including new dimensions and variables in the analysis complicates both the qualitative analysis and the assessment of the traditional dichotomy -a State is either a DS or not- as it opens a wide variety of possibilities in which States can be successful in certain dimensions but not in others. Therefore, this multidimensional approach opens the door to multiple types of DS according to their different multidimensional efforts/ 
performances. This, in turn, implies that all countries are potential objects of analysis, thus increasing the complexity associated with comparative qualitative methodologies.

In contrast with the previous studies, we pursue a comparative analysis that includes a large number of countries with a limited set of explanatory variables in order to build an international "taxonomy" of DS. Thus, we expand our analytical universe beyond developing countries by also including developed countries, as we want to assess public efforts on human development promotion across the world. Besides -as Block (2008) argued-, developed countries may present a developmental public approach that has not yet received the proper attention.

In particular, we opted to perform a cluster analysis, which is a numerical technique that is suitable for classifying a sample of heterogeneous countries in a limited number of groups, each of which is internally homogeneous in terms of the similarities between the countries that comprise it. Ultimately, the goal of cluster analysis is to provide classifications that are reasonably "objective" and "stable" (Everitt et al., 2011): "objective" in the sense that the analysis of the same set of countries by the same numerical methods produces similar classification; and "stable" in that the classification remains similar when new countries are added.

Specifically, hierarchical cluster analysis allows us to build a taxonomy of States with heterogeneous developmental profiles in order to divide them into a number of groups so that: $i$ ) each country belongs to one -and only one- group; ii) all countries are classified; iii) countries of the same group are, to some extent, internally "homogeneous"; and iv) countries of different groups are noticeably dissimilar. The advantage of this procedure is that the "association structure" between countries can be discerned, which -in our analysis- facilitates the identification of the key development characteristics of each cluster.

Cluster analysis is structured in two main stages. First, the selection of the clustering variables, which includes defining the dimensions and selecting the corresponding variables (proxies). And second, the selection of the clustering toolkit. Four guiding principles are applied when selecting the appropriate variables for each dimension: $i$ ) segment differentiation, ii) low correlation between variables, iii) optimal relation between sample size and cluster variables; and $i v$ ) high quality and availability of data.

Segment differentiation is assured first through the selection of three different dimensions. Two sub-dimensions in each dimension are also contemplated (see Table 1): "innovation" and "institutional quality" for the economic 
Table 1. Dimensions, indicators and sources

\begin{tabular}{|c|c|c|c|c|}
\hline Dimensions & Subdimensions & Proxies & Sources & Years \\
\hline \multirow[t]{2}{*}{$\begin{array}{l}\text { Economic } \\
\text { development }\end{array}$} & $\begin{array}{l}\text { Research, development } \\
\text { and innovation }\end{array}$ & $\begin{array}{l}\text { \% Public spending } \\
\text { on R+D+i over GDP }\end{array}$ & $\begin{array}{l}\text { World Bank (2016a) UNESCO } \\
\text { (2016) and OECD (2016) }\end{array}$ & $\begin{array}{l}2014 \text { or closest } \\
\text { available year }\end{array}$ \\
\hline & $\begin{array}{l}\text { Institutional } \\
\text { quality }\end{array}$ & $\begin{array}{l}\text { Government } \\
\text { effectiveness }\end{array}$ & World Bank (2016b) & $\begin{array}{l}2014 \text { or closest } \\
\text { available year }\end{array}$ \\
\hline \multirow[t]{2}{*}{$\begin{array}{l}\text { Social } \\
\text { development }\end{array}$} & Education & $\begin{array}{l}\% \text { Public spending } \\
\text { on education over GDP }\end{array}$ & $\begin{array}{l}\text { World Bank (2016a) and } \\
\text { UNESCO (2016) }\end{array}$ & $\begin{array}{l}2014 \text { or closest } \\
\text { available year }\end{array}$ \\
\hline & Health & $\begin{array}{l}\text { \% Public spending } \\
\text { on health over GDP }\end{array}$ & World Bank (2016a) & $\begin{array}{l}2014 \text { or closest } \\
\text { available year }\end{array}$ \\
\hline \multirow{2}{*}{$\begin{array}{l}\text { Democratic } \\
\text { participation and } \\
\text { good governance }\end{array}$} & Quality of democracy & Polity IV & $\begin{array}{l}\text { Center for Systemic Peace } \\
(2016)\end{array}$ & $\begin{array}{l}2014 \text { or closest } \\
\text { available year }\end{array}$ \\
\hline & $\begin{array}{l}\text { Participation } \\
\text { and inclusion }\end{array}$ & $\begin{array}{l}\text { Voice and } \\
\text { accountability }\end{array}$ & World Bank (2016b) & $\begin{array}{l}2014 \text { or closest } \\
\text { available year }\end{array}$ \\
\hline
\end{tabular}

Source: own elaboration.

dimension, following the economic institutional literature on Ds (Evans, 1995; Mazzucato, 2013); "education" and "health" for the social dimension, following the human development approach (Malik, 2013); and "democratic quality" and "voice and accountability" for the democratic dimension (Evans and Heller, 2013).

It is worth mentioning that cluster analysis works better with simple indicators rather than synthetic ones, so we were ultimately faced with a choice between input and output indicators. ${ }^{5}$ On one hand, input variables reflect the "public effort" to promote development, but they do not necessarily lead to "public performance" (this will depend on many factors). On the other hand, output variables work the other way around. Following the conceptual discussions on Ds (Mkandawire, 2001; Vu, 2007; Fritz and Menocal, 2007) and our conceptualization of multidimensional Ds (which is focused on public efforts devoted to promote human capacities and opportunities), we opt for "input variables" as proxies of public efforts. ${ }^{6}$

5 For a methodological justification on the preference for simple over synthetic indicators when running cluster analysis see Dolnicar and Grün (2008).

6 For an extensive discussion on the tension between development structures (input indicators) and development outcomes (output indicators), see Mkandawire (2001); Vu (2007) and Fritz and Menocal (2007). 
Finally, to assure segment differentiation we run the Pearson correlation test in order to check for problematic correlations between pairs of variables (see Appendix 1).

The test shows no problematic correlations between variables. ${ }^{7}$ Moreover, in terms of a reasonable relationship between sample size and the number of clustering indicators, we apply Formann's (1984) rule that recommends a minimum sample size of $2^{n}$, where $n$ equals the number of clustering variables. In our case, with a sample of 112 countries, the maximum $n$ is equal to six.

The second step is the selection of the clustering toolkit. We run a hierarchical clustering through an agglomerative clustering procedure, that is, a bottom-up construction of a tree-like structure in the course of the analysis. The main issue concerning this stage is the measurement of similarities/dissimilarities between pairs of countries. As we have both positive and negative values in our dataset, we choose the squared Euclidean distance, which is the square root of the sum of the squared differences in the variable values. And as we mix variables with different scales we also standardize the variables. ${ }^{8}$

Regarding the selection of the cluster algorithm, given the type of data used in our analysis (six continuous variables), three possibilities are the nearest neighbour method, the furthest neighbour method and the Ward's method (Everitt et al., 2011; Sarstedt and Mooi, 2014). Since there is no objective criterion for selecting the most appropriate method and the selection depends largely on the interpretability of the final results, we choose the method proposed by Ward (1963), in which the fusion of two clusters is based on the size of an error sum-of-squares criterion.

The objective at each stage is to minimize the increase in the total withincluster error sum of squares. In practical terms, the Ward's method has been proven to be especially suitable for building clusters with similar sizes, when no outliers are present (Everitt et al., 2011; Sarstedt and Mooi, 2014).

The next step is to decide on the number of Ds groups (that is, the number of clusters to retain from the data). This decision is based on three different criteria: the agglomeration schedule (see Appendix 2), the dendrogram (see Figure 2) and the variance ratio criterion (see Table 2).

According to Sarstedt and Mooi (2014), problematic correlations appear over 0.9.

Regarding the standardisation method, we use the "range -1 to 1 " which is deemed to be preferable than other methods "in most situations" (Sarstedt and Mooi and, 2014, p. 247). The analysis was conducted using SPSS software. 
The agglomeration schedule displays the clusters combined at each stage and the distances at which clusters merge (see Appendix 2). This schedule is used to determine the optimum number of country groups. By plotting these distances against the number of clusters we can identify a distinct break or "elbow" (that is, where an additional combination of two clusters occurs at a greatly increased distance). The number of clusters prior to the merge is the most probable solution.

Thus, and despite the high number of countries included in the graph, the scree plot shows a distinct break due to the increase in distance when switching from a three to a four-cluster solution (see Figure 1).

The dendrogram graphically displays the distances at which countries (and clusters of countries) are joined (see Figure 2).

The dendrogram is read from left to right: vertical lines are countries joined together; their position indicates the distance at which the mergers take place. This graph provides guidance in terms of the number of groups to retain, showing that a three-cluster solution is appropriate.

Figure 1. Elbow graph

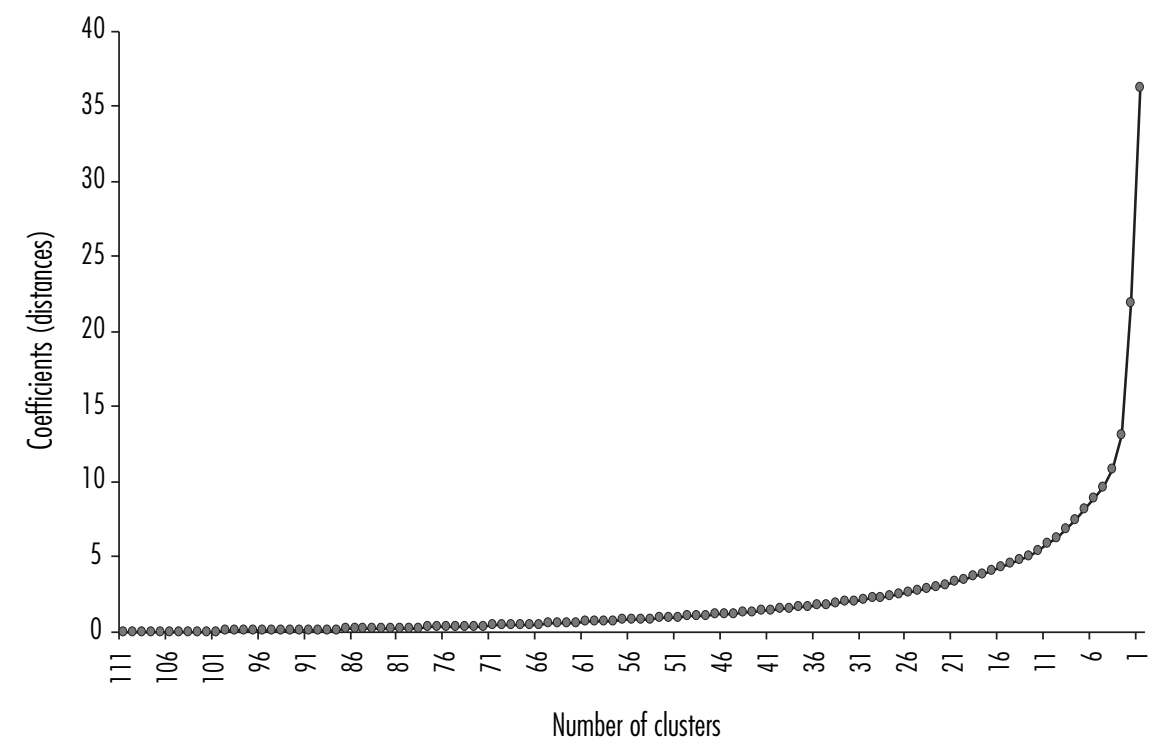

Source: own elaboration. 
Figure 2. Dendrogram

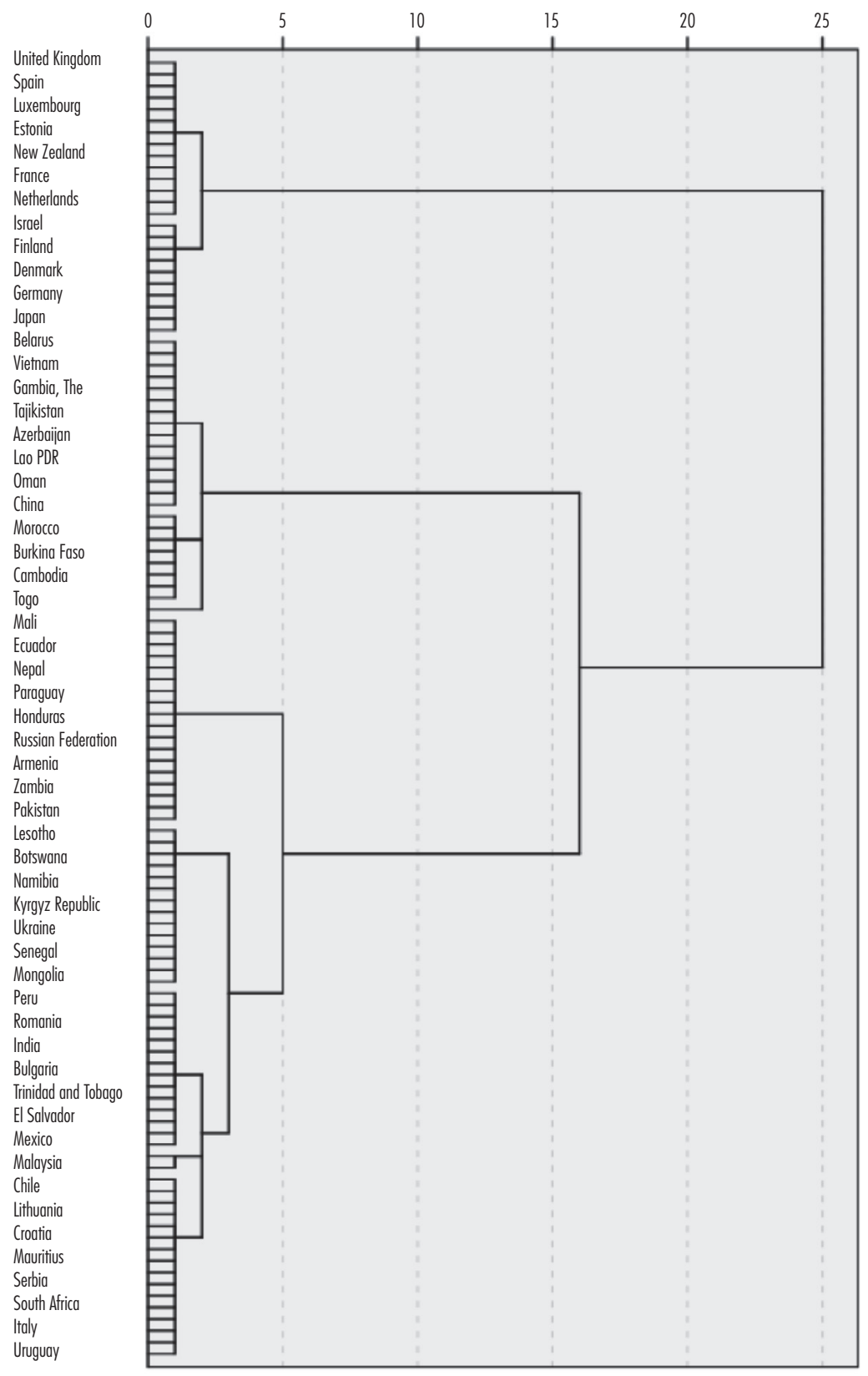

Source: own elaboration. 
Finally, Calinski and Harabasz (1974) proposed a more precise and objective method for determining the optimum number of clusters. The "variance ratio criterion" (VRC) recommends choosing the number of clusters that maximizes the ratio between the overall between-cluster variation and the overall within-cluster variation with regards to all clustering variables (that is, a good clustering yields groups of countries with small within-cluster variation but high between-cluster variation). In our case, this suggests that the optimum number of clusters is three (see Table 2).

Table 2. Variance ratio criterion (VRC)

\begin{tabular}{ccc}
\hline Num. clusters & VRC & Estadístico $w_{k}$ \\
\hline 2 & 798.88 &.. \\
3 & 710.41 & -135.52 \\
4 & 486.42 & 133.84 \\
5 & 396.25 & 133.54 \\
6 & 439.63 &.. \\
\hline
\end{tabular}

Source: own elaboration.

Therefore, using the three procedures (agglomeration schedule, dendrogram and VCR criterion) we determine the optimum number of clusters to be three. Before comparing the characteristics of these three clusters, we evaluate which variables are more influential in discriminating across countries. This step is particularly important as cluster analysis sheds light on whether the groups of countries are statistically distinguishable (that is, whether the clusters exhibit significantly different means in the development indicators).

It should be mentioned that the cluster solutions of our analysis are reasonably "robust". As recommended by Sarstedt and Mooi (2014), we verify the robustness of the cluster analysis with the following three-step check: first, we evaluate the stability of the results by using different clustering procedures, distance measures and standardization methods on the same data and test whether these yield similar taxonomies. However, one should bear in mind that -as noted by Everitt et al. (2011), among many others- results often change even when the cluster solution is adequate, so some degree of variation is expected when changing the cluster procedure. Secondly, we change the order of the countries in our data set and re-run the analysis to check the 
results' stability. The results should not depend on the order of the data set, unless there are outliers that influence the results. And thirdly, we replace one of the proxies -the Voice and accountability variable- with an alternative variable (Growth rate) for the same dimension.

The first check shows moderate variations in the results. In particular: i) changing the clustering procedure from Ward to the "link between groups" only affects 38 out of the 112 countries; ii) changing the distance measure from square Euclidian distance to Chebyshev distance only renders 1 differently classified country (Cuba); and iii) changing the standardization method from range -1 to 1 to the simple $\mathrm{z}$ standardization only renders 37 differently classified countries. The second check shows no variation in the results: changing the order of the countries in the data set does not affect the classification. Finally, the substitution of Voice and accountability for Growth rate only changes the classification of four countries.

All in all, cluster analysis (as a multivariate statistical analysis) implies certain limitations in various aspects that we must take into consideration. Three limitations are worth mentioning:?

First, the need to synthesize a complex and multidimensional concept, such as the public intervention of a developmental State, with a limited number of indicators implies a certain conceptual reductionism. This limitation is further reinforced by the methodological requirement of using simple versus synthetic indicators.

Second, including the developed countries in our taxonomy enlarges the analytical universe and allows us to build a complete international taxonomy, thus reflecting the whole range of developmental public interventionism patterns across the globe. However, this increase in the sample size also implies some analytical drawbacks, as it dilutes some interesting intra-cluster differentiations, especially among developing countries. We try to sort this out by extending the scope of the taxonomy in order to analyze sub-cluster patterns.

Third, in the particular case of the World Bank's "institutional quality indicator", some authors critize the "biases" of its design, its statistical sources and the "construct validity" of the indicator (Thomas, 2010). In any case, at present day this is the best and most comprehensive indicator available for the measurement of institutional quality with an internationally comparable database.

9 For an extensive discussion on the limitations of this methodological approach, see De la Cruz (2017). 


\section{RESULTS: A TAXONOMY FOR MULTIDIMENSIONAL DEVELOPMENTAL STATES}

Our cluster analysis produces a taxonomy of 112 States that are classified into three different groups (see Figure 2 and Appendix 3). A precise interpretation of the three clusters involves examining the cluster centroids (that is, the clustering variables' average values of all countries in a certain cluster). This comparative procedure enables us to analyse the data on the basis of the grouping variable's values. According to Table 3 the three Ds clusters can be described as follows:

Table 3. Centroids per cluster

\begin{tabular}{lccccccc}
\hline \multicolumn{2}{c}{ Clusters } & Innovation & Gov. effect. & Education & Health & Polity IV & Voice \\
\hline Cluster 1 & Mean & 2.41 & 1.50 & 5.54 & 9.79 & 9.71 & 1.29 \\
$(\mathrm{~N}=24)$ & St.dev & 0.83 & 0.33 & 1.14 & 2.29 & 0.62 & 0.31 \\
Cluster 2 & Mean & 0.49 & -0.04 & 4.76 & 6.62 & 7.61 & 0.05 \\
$(\mathrm{~N}=64)$ & St.dev & 0.41 & 0.68 & 2.05 & 2.08 & 2.28 & 0.59 \\
Cluster 3 & Mean & 0.35 & -0.53 & 4.34 & 5.84 & -4.63 & -1.12 \\
$(\mathrm{~N}=24)$ & St.dev & 0.41 & 0.46 & 2.17 & 1.95 & 2.93 & 0.46 \\
Total & Mean & 0.87 & 0.18 & 4.84 & 7.13 & 5.44 & 0.06 \\
$(\mathrm{~N}=112)$ & St.dev & 0.96 & 0.92 & 1.95 & 2.52 & 5.77 & 0.94 \\
\hline
\end{tabular}

Source: own elaboration.

- Human development States (Cluster 1). This cluster includes 24 developed countries (18 european countries, plus Australia, Canada, Israel, Japan, New Zealand, South Korea and the United States) that make the highest efforts on all three dimensions and their corresponding six proxies. It is worth noting that the dendrogram shows a subsequent formation of two sub-clusters, which are mainly differentiated in terms of their innovation efforts. Thus the first sub-cluster is composed of 10 countries with the highest relative investments in $\mathrm{R}+\mathrm{D}+\mathrm{i}$ (Israel, South Korea, Finland, Sweden, Denmark, Austria, Germany, Australia, Japan and Slovenia), whereas the second sub-cluster has relatively lower innovation efforts (which includes, among others, France, Spain, Portugal and Ireland). 
- Unbalanced developmental States (Cluster 2). This cluster is composed of 64 developed and developing countries. In particular, all Latin American countries (except Cuba), some South and East European countries and some African and Asian States are in this group. These States have low economic and social efforts with four indicators slightly under the overall average (Innovation, Government effectiveness, Education and Health). However, their Democratic quality is above the overall average, while Voice and accountability remains low but close to the average.

Furthermore, the dendrogram suggests a subdivision into two sub-clusters: countries above the average on the social and democratic dimensions (Uruguay, Italy, South Africa, Poland and Greece) and those below the average (Jamaica, Mongolia, Kenya, Ukraine, Namibia and Bolivia) (see Appendix 3).

There are, however, six countries that could be considered as outliers of this cluster: Singapore and Malaysia make important efforts on both economic indicators, while Brazil and Russia focus their efforts on innovation capacities, and Moldova and Lesotho make exceptional public efforts on health and education policies.

- Non-developmental States (Cluster 3). This cluster includes 24 States, all of them located in Asia, Africa and East Europe (non EU members). These States show anemic public efforts on the economic, democratic and social dimensions with all six proxies below the overall average.

Moreover, this cluster can be divided into three sub-clusters: countries with the worst figures on the democratic dimension (mainly autocracies or low density democracies such as Iran, Egypt or China); ${ }^{10}$ countries with slightly less negative figures on the democratic dimension (such as Jordan, Morocco and Thailand); and the particular case of Cuba, which makes an outstanding investment effort on heath and education.

This taxonomy shows that State devlopmentalism from a human development perspective is not only a phenomena associated to the East Asian States. Furthermore, while the traditional North-East Asian countries are included in the "human development States" cluster (such as Japan and South Korea) the other South-East Asian DS are included in the other two categories. On one hand, Singapur, Malasya and Indonesia are among the "unbalanced States", in spite of their remarkable performance on the economic dimension, as they 
make limited efforts on the social and democratic dimensions. On the other side, Thailand is considered a "non developmental States" as its public efforts are under the average in the economic and democratic dimensions.

Moreover, we explore whether the public efforts ("inputs") across DS clusters are finally transformed in developmental performance ("outputs"). Obviously, different levels of efficiency in public interventions can result on very different development outcomes. To test so we compute the average Human Development Index (HDI) for each of the three clusters.

The results show -as expected- a close correlation between inputs and outputs: "human development States" (C1) have the highest HDI, followed by the "unbalanced developmental States" (C2) and the "non-developmental States" (C3) (see Table 5). In particular, as the HDI does not include democratic indicators, it is not surprising that $\mathrm{C} 2$ and C3 have similarly low HDI averages.

Table 4. Average HDI per cluster

\begin{tabular}{ccc}
\hline $\begin{array}{c}\text { Human development } \\
\text { States } \\
(\mathrm{C} 1)\end{array}$ & $\begin{array}{c}\text { Unbalanced evelopmental } \\
\text { States } \\
\text { (C2) }\end{array}$ & $\begin{array}{c}\text { Non-developmental } \\
\text { States } \\
\text { (C3) }\end{array}$ \\
\hline 0.901 & 0.69 & 0.65
\end{tabular}

Source: own elaboration based on UNDP (2016).

Finally, it is worth mentioning that the differences between clusters are significant. According to the one-way ANOva analysis, which allows us to compare the differences across the cluster centroids, the six variables included in the classification are statistically significant (see Table 5 ).

The size of the $F$ statistics shows the relation between the overall betweencluster variation and the overall within-cluster variation and, therefore, it is a good indicator of the relevance of each variable for identifying groups of countries. According to this criterion, the variable with the greatest discriminating power in the classification is Democratic regime, followed by Innovation and Voice and accountability. By contrast, the variables with lowest relative importance are Education, Health and Government effectiveness. 
Table 5. One-way ANOVA

\begin{tabular}{|c|c|c|c|c|c|c|}
\hline & & Squares sum & $g l$ & Quadratic mean & $F$ & Sig. \\
\hline \multirow{3}{*}{$\begin{array}{l}\text { Public spending } \\
\text { on } R+D+i\end{array}$} & Inter-groups & (Combined) & 2 & 36.546 & 130.610 & 0.000 \\
\hline & Intra-groups & 30.499 & 109 & 0.280 & & \\
\hline & Total & 103.592 & 111 & & & \\
\hline \multirow{3}{*}{$\begin{array}{l}\text { Government } \\
\text { effectiveness }\end{array}$} & Inter-groups & (Combined) & 2 & 28.912 & 84.433 & 0.000 \\
\hline & Intra-groups & 37.325 & 109 & 0.342 & & \\
\hline & Total & 95.150 & 111 & & & \\
\hline \multirow{3}{*}{$\begin{array}{l}\text { Public spending } \\
\text { on education }\end{array}$} & Inter-groups & (Combined) & 2 & 9.071 & 2.439 & 0.092 \\
\hline & Intra-groups & 405.381 & 109 & 3.719 & & \\
\hline & Total & 423.523 & 111 & & & \\
\hline \multirow{3}{*}{$\begin{array}{l}\text { Public spending } \\
\text { on health }\end{array}$} & Inter-groups & (Combined) & 2 & 113.124 & 25.526 & 0.000 \\
\hline & Intra-groups & 483.055 & 109 & 4.432 & & \\
\hline & Total & 709.303 & 111 & & & \\
\hline \multirow[t]{3}{*}{ Polity IV } & Inter-groups & (Combined) & 2 & 1584.872 & 322.406 & 0.000 \\
\hline & Intra-groups & 535.818 & 109 & 4.916 & & \\
\hline & Total & 3705.563 & 111 & & & \\
\hline \multirow{3}{*}{$\begin{array}{l}\text { Voice and } \\
\text { accountability }\end{array}$} & Inter-groups & (Combined) & 2 & 34.989 & 129.927 & 0.000 \\
\hline & Intra-groups & 29.354 & 109 & 0.269 & & \\
\hline & & 99.332 & 111 & & & \\
\hline
\end{tabular}

Source: own elaboration.

\section{CONCLUSIONS}

Analysing Ds from a human development approach widens the scope beyond the economic policies in the East Asian region to the complexities of an international and multidimensional development landscape. Thus, the conceptualization of DS needs to shift from a restricted-economical-concept to a multidimensional - "development studies"- one. In our case we opt for a conceptualization of DS that includes two new dimensions, apart from economic development: social progress and democratic governance. 
Consequently, we understand that the scope of the analysis should not be restricted to countries that are focused on promoting income growth (the "traditional" Ds), but it should also include those States which promote opportunities and capacities to their citizens, thereby generating a complex progress of "human development". This is why we analyse a wider analytical universe that includes both developed and developing countries, and we run a hierarchal cluster analysis that allows us to build a reasonable taxonomy for 112 different States.

The results of our analysis show that the democratic and economic indicators are the two main drivers of our multidimensional taxonomy. We end up with three different groups:

i) The human developmental States, which include 90 percent of oCDE Members and are characterized by "sound" democratic institutions, broad Welfare States and important economic efforts.

ii) The unbalanced human development States, which are mainly located in Latin America and East Europe; they are characterized by low economic and social efforts but acceptable democratic quality.

iii) The non-developmental States, which are mainly autocracies and low-density democracies around the world with low economic, social and democratic efforts.

As expected, "human development States" do not only make the greatest efforts to promote development but they also have the highest performance in terms of their HDI. In contrast, "unbalanced developmental States" and "non-developmental States" have significantly lower HDI performances. Thus, expanding Block's (2008) argument on the presence of Ds in developed nations, we suggest that from an input/output multidimensional conceptualization, most developed nations show typical Ds features. On the other hand, while acknowledging significative progress in some dimensions, we refuse the recent literature argument raising the possibility of emerging Ds in some developing nations (Malik, 2013; Evans and Heller, 2013).

All in all, our multidimensional taxonomy offers a more complex understanding of the variety of public efforts devoted to promote human development, thus overcoming the restricted (economical) conception of DS, which is mainly focused to the East Asian region. For example, Japan and South Korea -two countries generally considered as Ds- fall in cluster 1 (human Ds), whereas Singapur, Malasya and Indonesia belong to cluster 2 (unbalanced Ds) due to their most restricted efforts on the social and democratic dimensions. 


\section{BIBLIOGRAPHY}

Alkire, S. (2002), "Dimensions of human development", World Development, vol. 30, no. 2, DoI <https://doi.org/10.1016/S0305-750X(01)00109-7> (2010), Human development: definitions, critiques, and related concepts, OPHI-Working Paper no. 36, UK, Oxford Poverty \& Human Development Initiative, University of Oxford .

Amsden, A. H. (1989), Asia's next giant: South Korea and late industrialization, Oxford, Oxford University Press.

Barro, R. J. (1996), "Democracy and growth", Journal of Economic Growth, vol. 1, no. 1. Available at <https://www.jstor.org/stable/40215879>

Berg, A., Ostry, J. D. and Zettelmeyer, J. (2012), "What makes growth sustained?", Journal of Development Economics, vol. 98, no. 2, DOI <https://doi. org/10.1016/j.jdeveco.2011.08.002>

Besley, T. and Kudamatsu, M. (2006), "Health and democracy", The American Economic Review, vol. 96, no. 2, DOI <10.1257/000282806777212053> and Kudamatsu, M. (2007), Making autocracy work, May. Available at SSRN <https://ssrn.com/abstract=1127017>

Block, F. (2008), "Swimming against the current: The rise of a hidden developmental state in the United States", Politics \& Society, vol. 36, no. 2, DOI <https://doi.org/10.1177/0032329208318731>

Boserup, E. (2007), Woman's role in economic development, London, Earthscan.

Calinski, T. and Harabasz, J. (1974), "A dendrite method for cluster analysis", Communications in Statistics-theory and Methods, vol. 3, no. 1, DOI $<10.1080 / 03610927408827101>$

Center for Systemic Peace (2016), Polity project. Retrieved January, 2016, from <http://www.systemicpeace.org/polityproject.html>

De la Cruz, F. (2014), "East Asian developmental states: institutional contributions and historical limits", Iberoamerican Journal of Development Studies, vol. 3, no. 2, DoI <https://doi.org/10.26754/ojs_ried/ijds.117> (2017), Estados desarrollistas en el siglo XXI: análisis de conglomerados para una taxonomía multidimensional, PhD Thesis, UNED.

Dolnicar, S. and Grün, B. (2008), "Challenging 'factor-cluster segmentation", Journal of Travel Research, vol. 47, no. 1, DOI <https://doi. org/10.1177/0047287508318910>

Doucouliagos, H. and Ulubaşoğlu, M. A. (2008), "Democracy and economic growth: a meta-analysis", American Journal of Political Science, 52, DOI $<10.1111 /$ j.1540-5907.2007.00299.x> 
Edigheji, O. (2010), "Constructing a democratic developmental state in South Africa: potentials and challenges", in Constructing a democratic developmental state in South Africa: potentials and challenges, Cape Town, Human Sciences Research Council Press.

Evans, P. (1995), Embedded autonomy: states and industrial transformation, Princeton, Princeton University Press.

(2008), "In search of the $21^{\text {st }}$ century developmental state", The Centre for Global Political Economy, Working Paper 4, University of Sussex.

Evans, P. and Heller, P. (2013), "Human development, state transformation and the politics of the developmental state", The Oxford Handbook of Transformations of the State, Oxford, Oxford University Press.

Everitt, B. S., Landau, S., Leese, M. and Stahl, D. (2011), Hierarchical clustering. Cluster Analysis, $5^{\text {th }}$ Edition, Wiley editors, DOI $<10.1002 / 9780470977811>$

Fritz, V. and Menocal, A. R. (2007), "Developmental states in the new millennium: concepts and challenges for a new aid agenda", Development Policy Review, vol. 25, no. 5, DoI <https://doi.org/10.1111 /j.1467-7679.2007.00384.x>

Formann, A. K. (1984), Die Latent-Class-Analyse: Einfuhrung in die Theorie und Anwendung, Beltz, Weinheim.

Gerring, J., Thacker, S. C. and Alfaro, R. (2012), "Democracy and human development", The Journal of Politics, vol. 74, no. 1, DoI <https://doi. org/10.1017/S0022381611001113>

Hanushek, E. A. and Woessmann, L. (2008), "The role of cognitive skills in economic development", Journal of Economic Literature, vol. 46, no. 3, DOI $<10.1257 /$ jel.46.3.607>

and Woessmann, L. (2012), "Do better schools lead to more growth? Cognitive skills, economic outcomes, and causation", Journal of Economic Growth, vol. 17, no. 4, DOI <10.1007/s10887-012-9081-x>

Hayashi, S. (2010), "The developmental state in the era of globalization: beyond the Northeast Asian model of political economy", The Pacific Review, vol. 23, no. 1, DOI <https://doi.org/10.1080/09512740903398 $330>$

Hsu, J. (2018), "The developmental state of the twenty-first century: accounting for state and society", Third World Quarterly, vol. 39, no. 6, DOI <https://doi.org/10.1080/01436597.2017.1357115>

Johnson, C. (1982), MITI and the Japanese miracle: the growth of industrial policy, Palo Alto, Stanford University Press. 
Kwon, H. J. (2005), "Transforming the developmental welfare state in East Asia", Development and Change, vol. 36, no. 3, DOI <10.1111/j.0012155X.2005.00420.x>

(2009), "The reform of the developmental welfare state in East Asia", International Journal of Social Welfare, 18: S12-S21, DOI <10.1111/j.14682397.2009.00655.x>

Leftwich, A. (1995), "Bringing politics back in: towards a model of the developmental state", The Journal of Development Studies, vol. 31, no. 3, DOI <https://doi.org/10.1080/00220389508422370>

Malik, K. (2013), Human development report 2013. The rise of the south: human progress in a diverse world. (March 15), UNDP-HDRO Human Development Reports.

Mazzucato, M. (2013), The entrepreneurial state: debunking public vs. private sector myths, London, Anthem Press.

McGuire, J. W. (2010), Wealth, health, and democracy in East Asia and Latin America, Cambridge, Cambridge University Press.

Mkandawire, T. (2001), "Thinking about developmental states in Africa", Cambridge Journal of Economics, vol. 25, no. 3, DoI <https://doi. org/10.1093/cje/25.3.289>

Nem Singh, J. and Ovadia, J. S. (2018), "The theory and practice of building developmental states in the Global South", Third World Quarterly, vol. 39, no. 6, DOI <https://doi.org/10.1080/01436597.2018.1455143>

Nussbaum, M. C. (2001), Women and human development: the capabilities approach, Cambridge, Cambridge University Press.

Organisation for Economic Co-operation and Development (OECD) (2016), OECD.Stat. Retrieved, January, from <http://stats.oecd.org/>

Ostry, J. D. and Berg, A. (2011), "Inequality and unsustainable Growth", IMF Staff Discussion Notes 11/08, Washington DC, International Monetary Fund.

Ostry, J. D., Berg, A. and Tsangarides, M. (2014), Redistribution, inequality, and growth, Washington DC, International Monetary Fund.

Ranis, G., Stewart, F. and Ramirez, A. (2000), "Economic growth and human development", World Development, vol. 28, no. 2, DoI <https://doi. org/10.1016/S0305-750X(99)00131-X>

Ranis, G., Stewart, F. and Samman, E. (2006), "Human development: beyond the human development index", Journal of Human Development, vol. 7 , no. 3, DOI <https://doi.org/10.1080/14649880600815917>

Redclift, M. and Springett, D. (2015), Routledge international handbook of sustainable development, London, Routledge. 
Robinson, M. and White, G. (1998), The democratic developmental state: political and institutional design, Oxfod, Oxford University Press.

Routley, L. (2012), "Developmental states: a review of the literature", ESID, Working Paper no. 03, February, DOI <http://dx.doi.org/10.2139/ssrn. 2141837>

Sandbrook, R., Edelman, M., Heller, P. and Teichman, J. (2007), Social democracy in the global periphery: origins, challenges, prospects, Cambridge, Cambridge University Press.

Sarstedt, M. and Mooi, E. (2014), A concise guide to market research: the process, data, and methods using IBM SPSS statistics, Springer.

Seers, D. (1969), “The meaning of development", International Development Review 11, UK, Institute of Deveelopment Studies.

Sen, A. (1999), Development as freedom, Oxford, Oxford University Press.

Shadlen, K. C. (2005), "Exchanging development for market access? Deep integration and industrial policy under multilateral and regional-bilateral trade agreements", Review of International Political Economy, vol. 12, no. 5, DOI <https://doi.org/10.1080/09692290500339685>

Streeten, P. (1984), "Basic needs: some unsettled questions", World Development, vol. 12, no. 9, DoI <https://doi.org/10.1016/0305-750X (84) $90054-8>$

Swilling, M., Musango, J. and Wakeford, J. (2016), "Developmental states and sustainability transitions: prospects of a just transition in South Africa", Journal of Environmental Policy \& Planning, vol. 18, no. 5, DOI <https://doi.org/10.1080/1523908X.2015.1107716>

Thomas, M. A. (2010), "What do the worldwide governance indicators measure?", The European Journal of Development Research, vol. 22, no. 1, DOI $<10.1057 /$ ejdr.2009.32>

unEsCo (2016), Science, techonology and innovation indicators. Retrieved from: <http://www.uis.unesco.org/ScienceTechnology/Pages/default.aspx>

United Nations Development Programme (UNDP) (2016), Human development report 2016: human development for everyone, New York, United Nations Development Programme.

$\mathrm{Vu}, \mathrm{T}$. (2007), "State formation and the origins of developmental states in South Korea and Indonesia", Studies in Comparative International Development, vol. 41, no. 4, DoI <https://doi.org/10.1007/BF02800470>

Wade, R. H. (1990), Governing the market: economic theory and the role of government in East Asian industrialization, Princeton, Princeton University Press. 
(2003), "What strategies are viable for developing countries today? The World Trade Organization and the shrinking of 'development space", Review of International Political Economy, vol. 10, num 4, DOI <https://doi. org/10.1080/09692290310001601902>

Ward Jr., J. H. (1963), "Hierarchical grouping to optimize an objective function", Journal of the American Statistical Association, vol. 58, no. 301, DOI <10.1080/01621459.1963.10500845>

Wong, C. M. L. (2012), "The developmental state in ecological modernization and the politics of environmental framings: The case of Singapore and implications for East Asia”, Nature and Culture, vol. 7, no. 1, DOI $<10.3167 /$ nc.2012.070106>

Woo-Cumings, M. (1999), The developmental state, New York, Cornell University Press.

World Bank (2016a), World Development Indicators, retrieved January, from $<$ http://data.worldbank.org/data-catalog/world-development-indicators> (2016b), World Governance Indicators, retrieved from <http://info. worldbank.org/governance/wgi/index.aspx\#home>

Yeung, H. W. C. (2014), "Governing the market in a globalizing era: developmental states, global production networks and inter-firm dynamics in East Asia”, Review of International Political Economy, vol. 21, no. 1, DOI <https://doi.org/10.1080/09692290.2012.756415>

\section{APPENDIX}

Appendix 1. Pearson correlation test

\begin{tabular}{|c|c|c|c|c|c|c|c|}
\hline & & Innovation & Gov effect & Education & Health & Polity IV & Voice \\
\hline \multirow[t]{3}{*}{ Innovation } & Pearson Corr & 1 & $.694^{* *}$ & $.208^{\star}$ & $.516^{\star \star}$ & $.340^{\star \star}$ & $.591^{\star \star}$ \\
\hline & Sig. (bilateral) & & 0 & 0.02 & 0 & 0 & 0 \\
\hline & N & 132 & 130 & 124 & 127 & 119 & 129 \\
\hline \multirow[t]{3}{*}{ Gov effect } & Pearson Corr & $694.000^{\star *}$ & 1 & 0.106 & $.331^{\star \star}$ & $.489^{\star \star \star}$ & $.788^{\star \star}$ \\
\hline & Sig. (bilateral) & 0 & & 0.159 & 0 & 0 & 0 \\
\hline & N & 130 & 201 & 177 & 184 & 163 & 196 \\
\hline \multirow[t]{3}{*}{ Education } & Pearson Corr & $.208^{\star}$ & 0.106 & 1 & $.407^{\star \star}$ & $.221^{\star \star}$ & $.286^{\star \star}$ \\
\hline & Sig. (bilateral) & 0.02 & 0.159 & & 0 & 0.006 & 0 \\
\hline & N & 124 & 177 & 181 & 175 & 151 & 175 \\
\hline
\end{tabular}


Sergio Tezanos and Fernando de la Cruz

Appendix 1. Pearson correlation test (continuation)

\begin{tabular}{|c|c|c|c|c|c|c|c|}
\hline & & Innovation & Gov effect & Education & Health & Polity IV & Voice \\
\hline \multirow[t]{3}{*}{ Health } & Pearson Corr & $.516^{\star \star}$ & $.331^{\star \star}$ & $.407^{\star \star}$ & 1 & $.460^{\star \star}$ & $.527^{\star \star}$ \\
\hline & Sig. (bilateral) & 0 & 0 & 0 & & 0 & 0 \\
\hline & $\mathrm{N}$ & 127 & 184 & 175 & 188 & 159 & 182 \\
\hline \multirow[t]{3}{*}{ Polity IV } & Pearson Corr & $.340^{\star \star}$ & $.489^{\star \star \star}$ & $.221^{\star \star}$ & $.460^{\star \star}$ & 1 & $.804^{\star \star}$ \\
\hline & Sig. (bilateral) & 0 & 0 & 0.006 & 0 & & 0 \\
\hline & $\mathrm{N}$ & 119 & 163 & 151 & 159 & 164 & 159 \\
\hline \multirow[t]{3}{*}{ Voice } & Pearson Corr & $.591^{\star \star}$ & $.788^{\star \star *}$ & $.286^{\star \star}$ & $.527^{\star \star}$ & $.804^{\star \star}$ & 1 \\
\hline & Sig. (bilateral) & 0 & 0 & 0 & 0 & 0 & \\
\hline & $\mathrm{N}$ & 129 & 196 & 175 & 182 & 159 & 198 \\
\hline
\end{tabular}

Notes: * Correlation is significant at 0,.5 (2 tails); ${ }^{\star \star}$ Correlation is significant at 0.01 level (2 tails).

Source: own elaboration.

Appendix 2. Aglomeration schedule

\begin{tabular}{|c|c|c|c|c|c|c|c|}
\hline \multirow{2}{*}{$\begin{array}{l}\text { Number of } \\
\text { conglomerates }\end{array}$} & \multirow[t]{2}{*}{ Stage } & \multicolumn{2}{|c|}{ Combined cluster } & \multirow[t]{2}{*}{ Ratios } & \multicolumn{2}{|c|}{ First cluster appearance stage } & \multirow[t]{2}{*}{ Next stage } \\
\hline & & Cluster 1 & Cluster 2 & & Cluster 1 & Cluster 2 & \\
\hline 111 & 1 & 32 & 43 & 0.000 & 0 & 0 & 51 \\
\hline 110 & 2 & 59 & 83 & 0.001 & 0 & 0 & 42 \\
\hline 109 & 3 & 4 & 22 & 0.004 & 0 & 0 & 41 \\
\hline 108 & 4 & 66 & 92 & 0.007 & 0 & 0 & 49 \\
\hline 107 & 5 & 26 & 84 & 0.013 & 0 & 0 & 51 \\
\hline 106 & 6 & 29 & 96 & 0.018 & 0 & 0 & 50 \\
\hline 105 & 7 & 7 & 30 & 0.024 & 0 & 0 & 45 \\
\hline 104 & 8 & 81 & 82 & 0.030 & 0 & 0 & 21 \\
\hline 103 & 9 & 73 & 85 & 0.036 & 0 & 0 & 62 \\
\hline 102 & 10 & 40 & 46 & 0.043 & 0 & 0 & 55 \\
\hline 101 & 11 & 67 & 69 & 0.049 & 0 & 0 & 19 \\
\hline 100 & 12 & 8 & 103 & 0.056 & 0 & 0 & 79 \\
\hline 99 & 13 & 5 & 50 & 0.063 & 0 & 0 & 59 \\
\hline 98 & 14 & 75 & 77 & 0.071 & 0 & 0 & 83 \\
\hline
\end{tabular}


A multidimensional taxonomy of developmental states

\begin{tabular}{|c|c|c|c|c|c|c|c|}
\hline \multirow{2}{*}{$\begin{array}{l}\text { Number of } \\
\text { conglomerates }\end{array}$} & \multirow[t]{2}{*}{ Stage } & \multicolumn{2}{|c|}{ Combined cluster } & \multirow[t]{2}{*}{ Ratios } & \multicolumn{2}{|c|}{ First cluster appearance stage } & \multirow[t]{2}{*}{ Next stage } \\
\hline & & Cluster 1 & Cluster 2 & & Cluster 1 & Cluster 2 & \\
\hline 97 & 15 & 9 & 80 & 0.080 & 0 & 0 & 43 \\
\hline 96 & 16 & 17 & 65 & 0.088 & 0 & 0 & 49 \\
\hline 95 & 17 & 25 & 35 & 0.097 & 0 & 0 & 30 \\
\hline 94 & 18 & 45 & 54 & 0.106 & 0 & 0 & 98 \\
\hline 93 & 19 & 24 & 67 & 0.116 & 0 & 11 & 56 \\
\hline 92 & 20 & 55 & 78 & 0.126 & 0 & 0 & 75 \\
\hline 91 & 21 & 81 & 86 & 0.136 & 8 & 0 & 40 \\
\hline 90 & 22 & 21 & 27 & 0.148 & 0 & 0 & 82 \\
\hline 89 & 23 & 39 & 61 & 0.159 & 0 & 0 & 42 \\
\hline 88 & 24 & 94 & 106 & 0.171 & 0 & 0 & 28 \\
\hline 87 & 25 & 64 & 79 & 0.183 & 0 & 0 & 68 \\
\hline 86 & 26 & 13 & 34 & 0.195 & 0 & 0 & 52 \\
\hline 85 & 27 & 10 & 44 & 0.207 & 0 & 0 & 65 \\
\hline 84 & 28 & 36 & 94 & 0.220 & 0 & 24 & 55 \\
\hline 83 & 29 & 2 & 57 & 0.233 & 0 & 0 & 64 \\
\hline 82 & 30 & 25 & 28 & 0.246 & 17 & 0 & 44 \\
\hline 81 & 31 & 51 & 90 & 0.260 & 0 & 0 & 72 \\
\hline 80 & 32 & 37 & 76 & 0.275 & 0 & 0 & 56 \\
\hline 79 & 33 & 6 & 38 & 0.290 & 0 & 0 & 62 \\
\hline 78 & 34 & 11 & 52 & 0.305 & 0 & 0 & 71 \\
\hline 77 & 35 & 14 & 74 & 0.321 & 0 & 0 & 45 \\
\hline 76 & 36 & 48 & 62 & 0.336 & 0 & 0 & 53 \\
\hline 75 & 37 & 1 & 68 & 0.353 & 0 & 0 & 46 \\
\hline 74 & 38 & 12 & 93 & 0.370 & 0 & 0 & 87 \\
\hline 73 & 39 & 18 & 110 & 0.386 & 0 & 0 & 73 \\
\hline 72 & 40 & 41 & 81 & 0.405 & 0 & 21 & 54 \\
\hline 71 & 41 & 3 & 4 & 0.424 & 0 & 3 & 60 \\
\hline 70 & 42 & 39 & 59 & 0.444 & 23 & 2 & 48 \\
\hline 69 & 43 & 9 & 100 & 0.464 & 15 & 0 & 67 \\
\hline \multirow[t]{2}{*}{68} & 44 & 25 & 99 & 0.485 & 30 & 0 & 76 \\
\hline & & & & & & & Continue \\
\hline
\end{tabular}


Sergio Tezanos and Fernando de la Cruz

Appendix 2. Aglomeration schedule (continuation)

\begin{tabular}{|c|c|c|c|c|c|c|c|}
\hline \multirow{2}{*}{$\begin{array}{l}\text { Number of } \\
\text { conglomerates }\end{array}$} & \multirow[t]{2}{*}{ Stage } & \multicolumn{2}{|c|}{ Combined cluster } & \multirow[t]{2}{*}{ Ratios } & \multicolumn{2}{|c|}{ First cluster appearance stage } & \multirow[t]{2}{*}{ Next stage } \\
\hline & & Cluster 1 & Cluster 2 & & Cluster 1 & Cluster 2 & \\
\hline 67 & 45 & 7 & 14 & 0.508 & 7 & 35 & 83 \\
\hline 66 & 46 & 1 & 47 & 0.534 & 37 & 0 & 72 \\
\hline 65 & 47 & 15 & 20 & 0.560 & 0 & 0 & 78 \\
\hline 64 & 48 & 39 & 70 & 0.588 & 42 & 0 & 78 \\
\hline 63 & 49 & 17 & 66 & 0.615 & 16 & 4 & 67 \\
\hline 62 & 50 & 23 & 29 & 0.643 & 0 & 6 & 90 \\
\hline 61 & 51 & 26 & 32 & 0.670 & 5 & 1 & 69 \\
\hline 60 & 52 & 13 & 72 & 0.698 & 26 & 0 & 93 \\
\hline 59 & 53 & 48 & 98 & 0.727 & 36 & 0 & 95 \\
\hline 58 & 54 & 41 & 42 & 0.756 & 40 & 0 & 66 \\
\hline 57 & 55 & 36 & 40 & 0.788 & 28 & 10 & 73 \\
\hline 56 & 56 & 24 & 37 & 0.820 & 19 & 32 & 80 \\
\hline 55 & 57 & 101 & 105 & 0.854 & 0 & 0 & 71 \\
\hline 54 & 58 & 31 & 87 & 0.887 & 0 & 0 & 77 \\
\hline 53 & 59 & 5 & 56 & 0.922 & 13 & 0 & 85 \\
\hline 52 & 60 & 3 & 49 & 0.958 & 41 & 0 & 61 \\
\hline 51 & 61 & 3 & 95 & 0.996 & 60 & 0 & 90 \\
\hline 50 & 62 & 6 & 73 & 1.034 & 33 & 9 & 80 \\
\hline 49 & 63 & 53 & 104 & 1.077 & 0 & 0 & 70 \\
\hline 48 & 64 & 2 & 112 & 1.120 & 29 & 0 & 89 \\
\hline 47 & 65 & 10 & 109 & 1.164 & 27 & 0 & 86 \\
\hline 46 & 66 & 41 & 102 & 1.209 & 54 & 0 & 88 \\
\hline 45 & 67 & 9 & 17 & 1.257 & 43 & 49 & 74 \\
\hline 44 & 68 & 64 & 111 & 1.306 & 25 & 0 & 89 \\
\hline 43 & 69 & 26 & 60 & 1.354 & 51 & 0 & 82 \\
\hline 42 & 70 & 53 & 97 & 1.404 & 63 & 0 & 79 \\
\hline 41 & 71 & 11 & 101 & 1.456 & 34 & 57 & 84 \\
\hline 40 & 72 & 1 & 51 & 1.511 & 46 & 31 & 84 \\
\hline 39 & 73 & 18 & 36 & 1.572 & 39 & 55 & 87 \\
\hline
\end{tabular}


A multidimensional taxonomy of developmental states

\begin{tabular}{|c|c|c|c|c|c|c|c|}
\hline \multirow{2}{*}{$\begin{array}{l}\text { Number of } \\
\text { conglomerates }\end{array}$} & \multirow[t]{2}{*}{ Stage } & \multicolumn{2}{|c|}{ Combined cluster } & \multirow[t]{2}{*}{ Ratios } & \multicolumn{2}{|c|}{ First cluster appearance stage } & \multirow[t]{2}{*}{ Next stage } \\
\hline & & Cluster 1 & Cluster 2 & & Cluster 1 & Cluster 2 & \\
\hline 38 & 74 & 9 & 33 & 1.639 & 67 & 0 & 88 \\
\hline 37 & 75 & 55 & 88 & 1.708 & 20 & 0 & 85 \\
\hline 36 & 76 & 25 & 89 & 1.778 & 44 & 0 & 86 \\
\hline 35 & 77 & 31 & 108 & 1.850 & 58 & 0 & 92 \\
\hline 34 & 78 & 15 & 39 & 1.922 & 47 & 48 & 97 \\
\hline 33 & 79 & 8 & 53 & 1.994 & 12 & 70 & 95 \\
\hline 32 & 80 & 6 & 24 & 2.077 & 62 & 56 & 101 \\
\hline 31 & 81 & 58 & 63 & 2.160 & 0 & 0 & 102 \\
\hline 30 & 82 & 21 & 26 & 2.245 & 22 & 69 & 100 \\
\hline 29 & 83 & 7 & 75 & 2.329 & 45 & 14 & 94 \\
\hline 28 & 84 & 1 & 11 & 2.424 & 72 & 71 & 93 \\
\hline 27 & 85 & 5 & 55 & 2.520 & 59 & 75 & 96 \\
\hline 26 & 86 & 10 & 25 & 2.622 & 65 & 76 & 99 \\
\hline 25 & 87 & 12 & 18 & 2.730 & 38 & 73 & 97 \\
\hline 24 & 88 & 9 & 41 & 2.843 & 74 & 66 & 107 \\
\hline 23 & 89 & 2 & 64 & 2.989 & 64 & 68 & 92 \\
\hline 22 & 90 & 3 & 23 & 3.154 & 61 & 50 & 98 \\
\hline 21 & 91 & 71 & 91 & 3.320 & 0 & 0 & 106 \\
\hline 20 & 92 & 2 & 31 & 3.510 & 89 & 77 & 101 \\
\hline 19 & 93 & 1 & 13 & 3.705 & 84 & 52 & 102 \\
\hline 18 & 94 & 7 & 107 & 3.905 & 83 & 0 & 100 \\
\hline 17 & 95 & 8 & 48 & 4.115 & 79 & 53 & 103 \\
\hline 16 & 96 & 5 & 16 & 4.342 & 85 & 0 & 99 \\
\hline 15 & 97 & 12 & 15 & 4.570 & 87 & 78 & 106 \\
\hline 14 & 98 & 3 & 45 & 4.828 & 90 & 18 & 105 \\
\hline 13 & 99 & 5 & 10 & 5.093 & 96 & 86 & 104 \\
\hline 12 & 100 & 7 & 21 & 5.425 & 94 & 82 & 105 \\
\hline 11 & 101 & 2 & 6 & 5.841 & 92 & 80 & 109 \\
\hline 10 & 102 & 1 & 58 & 6.268 & 93 & 81 & 108 \\
\hline 9 & 103 & 8 & 19 & 6.849 & 95 & 0 & 104 \\
\hline
\end{tabular}


Sergio Tezanos and Fernando de la Cruz

Appendix 2. Aglomeration schedule (continuation)

\begin{tabular}{lccccccc}
\hline \multirow{2}{*}{$\begin{array}{l}\text { Number of } \\
\text { conglomerates }\end{array}$} & Stage & \multicolumn{2}{c}{ Combined cluster } & Ratios & First cluster appearance stage & \multirow{2}{*}{ Next stage } \\
\cline { 3 - 6 } & & Cluster $~$ & Cluster 2 & & Cluster 1 & Cluster 2 & \\
\hline 8 & 104 & 5 & 8 & 7.491 & 99 & 103 & 110 \\
7 & 105 & 3 & 7 & 8.191 & 98 & 100 & 111 \\
6 & 106 & 12 & 71 & 8.893 & 97 & 91 & 107 \\
5 & 107 & 9 & 12 & 9.679 & 88 & 106 & 108 \\
4 & 108 & 1 & 9 & 10.841 & 102 & 107 & 109 \\
3 & 109 & 1 & 2 & 13.128 & 108 & 101 & 110 \\
2 & 110 & 1 & 5 & 21.929 & 109 & 104 & 111 \\
1 & 111 & 1 & 3 & 36.211 & 110 & 105 & 0 \\
\hline
\end{tabular}

Source: own elaboration.

Appendix 3. Countries/states per cluster and sub-cluster

Human developmental states (cluster 7)

Sub-cluster C.1.1: Israel, South Korea, Finland, Sweden, Denmark, Austria, Germany, Australia, Japan, Slovenia.

Sub-cluster C.1.2: United Kingdom, Ireland, Spain, Portugal, Luxembourg, Czech Republic, Estonia, Norway, New Zealand, Belgium, France, Canada, Netherlands, United States.

Unbalanced developmental states (cluster 2)

Sub-cluster C.2.1: Mali, Mozambique, Ecuador, Guatemala, Nepal, Nicaragua, Paraguay, Burundi, Honduras, Gabon, Russia, ${ }^{*}$ Venezuela, Bolivia, Lesotho, Moldova, Botswana, Ghana, Jamaica, Kenya, Kyrgyztan, Mongolia, Namibia, Senegal, Tunisia, Armenia, Sri Lanka, Zambia, Madagascar, Pakistan, Congo Rep.

Sub-cluster C.2.2: Argentina, Peru, Philippines, Romania, Indonesia, India, Turkey, Bulgaria, Panama, Trinidad and Tobago, Macedonia, Ucraine, El Salvador, Colombia, Mexico, Georgia, Malaysia, ${ }^{\star}$ Singapore, , Chile, Cyprus, Lithuania, Poland, Croatia, Latvia, Mauritius, Brazil, ${ }^{\star}$ Serbia, Costa Rica, South Africa, Hungary, Italy, Slovak Rep, Uruguay and Greece.

Non-developmental states (cluster 3)

Sub-cluster C.3.1: Belarus, Iran, Vietnam, Egypt, Gambia, Ethiopia, Taijkistan, Sudan, Azerbaijan, Kazakhstan, Lao, Kuwait, Oman, Saudi Arabia, China.*

Sub-cluster C.3.2: Jordan, Morocco, Thailand, Burkina Faso, Tanzania, Cambodia, Uganda, Togo.

Sub-cluster C.3.3: Cuba. *

Note: * exceptional cases: Cuba, Lesotho, Moldova, China, Singapore, Malaysia, Russia, China and Brazil.

Source: own elaboration. 